\title{
Towards Capacity Building: Rejecting Hiring Practices Based on Accent and Skin Colour
}

\author{
Teresa L. Van Deven (University of Western Ontario)
}

\begin{abstract}
As Cambodia begins the process of capacity building in higher education, now becomes the crucial time to revisit language policies practiced in other parts of Asia as a way of caution to the prevailing philosophical, educational and theoretical ideologies that are so very much a part of language education. This paper looks at the hiring practices based upon accent and skin colour. It includes part of a critical ethnographical study that looks at various linguistic and pedagogical fallacies which continue to promote the dominant fiction of native-speaker authority. This paper addresses implications on language education within a system which perpetuates both prejudice and discrimination of nonnative scholars. Higher education building in Cambodia means new beginnings, newly found freedom-I ask the question, to what extent can there be new beginnings if we continue to see remnants and echoes of Crusoe and Professor Higgins reverberating throughout the ELT classroom?

Résumé

Comme le Cambodge commence un processus de formation en compétences dans l'éducation supérieure, il est temps de réviser les politiques linguistiques utilisées dans d'autres pays asiatiques afin d'éviter les idéologies philosophiques, théoriques et éducatives, généralement représentatives de l'éducation en langue. Cet article analysera plus spécifiquement les pratiques d'embauche basées sur l'accent et la couleur de peau. Il inclut une étude de cas ethnographique critique qui examine plusieurs erreurs linguistiques et pédagogiques qui continuent à promouvoir l'autorité des locuteurs natifs. Cet article traite des implications que cette idée entraine dans l'éducation des langues au sein d'un système qui perpétue les préjudices et la discrimination des professeurs non natifs. La formation en compétences de l'éducation supérieure au Cambodge fait référence à un nouveau commencement, à une nouvelle paix mais je me demande s'il peut vraiment $\mathrm{y}$ avoir un nouveau commencement si nous continuons à voir les vestiges et à entendre les échos de Crusoe et du Professeur Higgins qui résonnent dans les salles de classes d'anglais langue étrangère ?
\end{abstract}

As we look at building capacity in Cambodia, this time becomes the most opportune moment to revisit language policies throughout the world and most specifically Asia. I would like to revisit some of the language policies practiced in other parts of Asia as a way of offering caution to the prevailing philosophical, educational and theoretical ideologies that are so very much a part of language education throughout the world. First, I will delve into the linguistic concept of "native speaker" as the arbiter of grammaticality and acceptability of language and discuss how this concept has predicated the long-standing role of the native speaker within so many educational systems within Asia. Secondly, I 
will focus on one educational system to further demonstrate the prevalence of this linguistic concept, and finally I will discuss the implications on an educational system that perpetuates both prejudice and discrimination of nonnative scholars.

I ask the question, how has the native-English speaker become what Pennycook describes as: "that idealized person with a complete and possibly innate competence in the language" (1994, p. 175)? I begin by trying to unravel the nexus of causes and consequences of the native-speaker fallacy. For an interpretation of the term 'native speaker' linguist Savignon (2003) decided to consult the Webster's International Dictionary, 2nd Edition. She found, however, that it was not very helpful. She describes what she found: “....among expressions containing 'native' as a modifer, 'native bear', 'native bread', 'native cabbage,' 'native dog', and 'native sparrow'. There is no mention of native speaker ( p. 20). As Savignon concludes, native speakers of any language do not own the language they use; nor are they automatically more competent to teach and evaluate learners. And so, perhaps the next question should be-what are the origins of this world-wide strongly held "native speaker fallacy" (Phillipson, 1992)? Why does this notion of the native speaker carry so much importance in the ESL/EFL context?

I have often found myself wondering why these assumptions around 'native speaker' have prevailed throughout the ages. As a teacher of English as a second language, I have found myself searching for the many reasons as to why these assumptions have had such staying power within the discourse of English language teaching and so, I decided to look for some of those answers through literature. I have specifically re-visited two of my beloved novels: Robinson Crusoe and Pygmalion.

Paley and Jipson (2002) state that books are not ideologically neutral objects "that is, they reflect and convey certain sets of socio cultural values, beliefs and attitudes to their readers" (p. 41). They state that "when abstract material is connected to vicissitudes of daily life through fictional structures and characterizations, its intensity seems to have an existence that is remarkably enduring” (p. 84). And so, why Robinson Crusoe? It would be an oversimplification to suggest that Defoe's model of the native-English speaker is the cause of the elevated status that native-English teachers enjoy today, and especially in Hong Kong, but it would perhaps be enough to suggest that the very category of native-speaker competence needs to be re-evaluated, re-visited so as to begin stripping the mystique-a mystique that is continually perpetuated in such works of literature as Robinson Crusoe. Joyce, as cited in Hamm, 1996, once stated that Crusoe is the "prototype of the British colonist as Friday (the true savage who arrives on an unlucky day) is the symbol of all subject races" (p. 118). Many of the concepts found throughout Crusoe's adventures predict and foreshadow the modern age, and most specifically, in terms of the many facets of colonial relationships within the English language classrooms 
throughout Asia. Fiction offers us a discourse that is often times used in nonfiction situations; fiction is one of the many sources of how we make sense of our world.

Why Pygmalion? This particular piece of literature focuses on issues of language and identity as well as the notion of 'Standard' English as a second language. While Eliza Doolittle did not learn a second or foreign language, the language issue explored within this play is still current today as educators continue to argue about replacing students' native language patterns (dialects) with Standard English. Even within the second language classroom, it is not enough for students to learn the new vocabulary, they must also learn to write and more importantly, to speak, using Standard English patterns. Although there are examples of scholarly work in 'dialect' being addressed within Canada, the US and Britain, it appears as though even today, there still exists a promise that Standard English is clearer and more amenable than other various dialects/forms (Parakrama, 1995). Indeed, Eliza does eventually adopt the 'new speech' yet her 'grove lingo' continues to define her social position.

While it is not my intention to provide a history lesson, it becomes vital to the discussion at hand to acknowledge the origins of this fallacy. Were there pedagogically sound criteria involved in the origins? Is the notion of nativespeaker superiority legitimate and based upon sound theoretical foundations? The origins of a number of fallacies regarding English language teaching can be traced to the Commonwealth Conference on Teaching of English as a Second Language held in Makarere, Uganda in 1961. Phillipson (1992) states that this conference bestowed legitimacy to many of the beliefs of a profession that had little theoretical foundation or pedagogical methods. One of the key tenets of the conference was "the ideal teacher of English is a native speaker (Phillipson, p. 185). This tenet dictates that native speakers have a better command of fluent, idiomatically correct language forms, are more knowledgeable about the cultural connotations of a language and are the final arbiters of the "acceptability of any given samples of language" (p. 194). Despite the weaknesses of this tenet, the long lasting and sustaining effects on the teaching of both EFL and ESL contexts is rather amazing, to say the least.

The weaknesses of this tenet are many:

1. The features attributed to native speakers can be instilled through teacher training,

2. Insights into the language process, such as the correct forms, the appropriate use of the language and the ability to analyze and explain the language are within the reach of the non-native teacher as well, and

3. The fact that a non-native speaker of a language has undergone the process of learning a language makes them better qualified to teach the language than those born with it (Phillipson, 1992).

Another element that has strongly contributed to keeping the "fiction" of nativespeaker competency alive is the focus on spoken communicative competence in 
foreign language pedagogy that has dominated since the 1960's. Perhaps it has been overlooked that native speakers do not speak an idealized standarized version of their language as their speech is influenced by geography, occupation, age and the social status of the speaker. The insistence of employing native speakers has made them both "custodians and arbiters of not only proper English but also of proper pedagogy as well” (Widdowson, 1994, p.387). In many cases, while it can be argued that the native speaker may be aware of the appropriate contexts of language use, he/she may not be better aware of the contexts of language learning.

And so, what are the linguistics of the fallacy? It has been argued that the native speaker fallacy goes against basic linguistic assumptions (Canagarajah, 1999, p. 79-80):

1. It is taken for granted that all language and dialects are of equal status.

2. There is no linguistic reason for the superiority of one dialect or language over another.

3. Language in the situation of context will always undergo modes of indigenization or vernacularization.

4. Language learning is a creative cognitive and social process that has its trajectory not fully dependent on the teacher and much less on the teacher's accent.

Despite the fact that the native speaker fallacy is pedagogically and linguistically anachronistic, the endorsement of the value of the native speaking teacher prevails----perhaps the Chairman of the British Council's statement in his Annual Report (1983-4) sums up this ideology behind the role of the native speaker best:

Our language is our greatest asset, greater than the North Sea Oil, and the supply is inexhaustible; furthermore, while we do not have a monopoly, our particular brand remains highly sought after. I am glad to say that those who guide the fortunes of this country share my conviction in the need to invest in and exploit to the full, this invisible, God-given asset (as quoted in Phillipson, 1992, pp. 144-45).

And so, in order to further ascertain to what extent these linguistic and pedagogical fallacies or god-given assets regarding native-speaking teachers have prevailed in a real educational setting, I travelled to Hong Kong to conduct a critical ethnographical study by following both a native-English speaking teacher and a Chinese-English speaking teacher. I observed and participated in their English classrooms for many months. I chose a school that would allow me to follow two these teachers because they were both teaching the exact same lessons within the curriculum. For two months, I visited these two classrooms each day. Both teachers were teaching a unit on past tense verbs - I chose this particular unit because throughout my 20 years as an ESL teacher, I noted that acquisition of tenses was problematic for Chinese students. 
Mr. Lau

Mr. Lau is a local Chinese-English teacher and has been teaching English at the secondary level for 9 years - at the time of my observation, he had obtained an undergraduate degree in English in Hong Kong and had just completed a master's degree in English Language Teaching.

When I met Mr.Lau he immediately apologized for his poor English despite the fact that he was a fluent speaker of English and had completed all his degrees in English. He reiterated that he was very fortunate because his school had 3 native-English speaking teachers-he said that they had VIP status and that he felt that the school should do more to tap into these teacher's experiences-he said he thought they should be giving seminars and workshops to the non-native teachers of English.

\section{Mr. Smith}

Mr. Smith had been teaching in Hong Kong for 10 years; he had received an undergraduate degree in Economics in England and had completed his teaching degree in Hong Kong. Mr. Smith had had no formal ESL training before coming to Hong Kong. He stated that he had "learned along the way".

When asked about his perceptions Mr. Smith said many of the ChineseEnglish speaking teachers used archaic methods for teaching; he said that the students told him that they found the classes boring; he felt that local teachers were just not "very fluent". He felt that if he were given the role of English Department co-ordinator, he could teach the local teachers better methods.

\section{Mr Smith's lessons}

During the first week, Mr. Smith used the class time to review regular and irregular verbs-he used the fill-in-the blank worksheets and quizzes-he liked to play Hangman with the class. The class was very excited but unruly and discipline was non-existent. Mr. Smith felt that students could use the past tense in their textbook, but when asked to speak or do any kind of writing, they would use only present tense verbs. I asked him if he thought that it may have something to do with transfer from first language-research has shown that for Chinese students, L1 transfer prolonged the pragmatic and lexical periods in the tense-aspect acquisition and that it was generally not until the first year of university that learners could be said to have acquired the native norms of using tense-aspect morphology. Mr. Smith, however, (who does not speak Cantonese) felt that students were just stubborn and resistant.

During the second week, Mr. Smith decided to use a video to reinforce past tense verbs-he chose Matilda. He agreed that the dialogue was far too difficult but that as the video was full of action, the students would be very interested. I found that the students were interested for about the first 5 minutes of the class, however, after that first five minutes of excitement, the students were either sleeping, talking or text messaging. At the end of the week, the 
movie was finished and students were asked to go home to write a composition about what had happened in the movie-from beginning to end. They were to use past tense verbs to explain.

Mr. Smith shared the compositions with me. Most students wrote fewer than 100 words (the instructions were to write 200). Very few used past tense verbs; many compositions were exactly the same; one industrious student downloaded a movie review of the film—sadly, it was in Spanish. It would appear that this video was both too long in duration (it took six classes to complete) and far too difficult for the students' level of English.

During week three, the students were put into groups of four to work together to present their version of the video-chaos prevailed and $\mathrm{Mr}$ smith was very unhappy with the overall presentations. As I circulated throughout the room, I found that the students used their first language to plan their presentation, however, once the presentations began, most groups were unable to express themselves and the presentations seemed to disintegrate into chaos and embarrassment for the students. Class discipline was so poor that while the groups presented, the rest of the class continued to talk and paid little or no attention to each presentation.

When I asked Mr. Smith about the results of these first three weeks, he said that the problem was that he was not given the good students; he said that he should never be given the poor or weak students because he felt that was a waste of his time.

\section{Mr. Lau's Lesson}

During the first two weeks , Mr. Lau introduced two new stories to the classboth were about one page long and focused on past tense verbs. Mr. Lau worked with these stories by instructing the students to re-tell the stories by changing the story into different tenses, and then by re-writing the stories with different endings. He chose the stories based upon the cues offered to students-he said that such phrases as "after that" "then", "the next morning" helped prompt the students into remembering verb changes. In week three, he gave the students two choices to write a composition: one choice was to compare the two stories and tell how they were different; another choice was to continue writing the stories and tell what happened after the end of the story. By the end of the three weeks, almost all of the students within the class felt comfortable with one of the stories and they were able to talk about the story using past tense with a level of confidence.

Mr. Lau told me that this type of writing activity tapped into the various skills of his students; his very creative students were given a medium to further explore that side of their writing, and for those who were the weaker students, there was enough scaffolding and structure to support them so that they too could feel a sense of accomplishment. Mr. Lau devoted two full-class periods for the students to write their final compositions. During the class time, 
he walked around and helped with spelling and tenses-once he collected the stories, he highlighted any errors, had the students correct them, and then had each student re-write their finalized copy. Over all, he felt the students had done very well.

When asked about these three weeks, again, Mr. Lau apologized for his poor English-he then said that it would have been much better if he were a native-speaker because then the students would have been exposed to 'authentic' English. While making this statement, I noted that at no time did Mr. Lau use Cantonese in his class-he conducted each and every class in English. I asked Mr. Lau why he felt he could not use any Cantonese during the class and he said that it was seriously frowned upon and that if the Department Head were to hear, there would be a poor evaluation.

Again, this speaks to the monolingual fallacy-within this fallacy, first language is not considered to play a useful function in the acquisition of English and it is considered to harm the process of second language acquisition. Mr. Lau was reluctant to speak about his own fluency in all three languages-English, Cantonese and Mandarin. He would offer very few comments about how his knowledge of learning a second and third language could be seen both as a helpful teaching tool and also as a very positive role model for his students. Teachers with multi-lingual competence develop a deep metalinguistic knowledge and complex language awareness and may therefore be even more effective teachers than so- called 'native speakers.' There is an insider-status (Auerbach, 1993) that provides teachers with an intimate awareness of the learning styles, language attitudes and functional needs of the students.

This is but one example of how two teachers approach the same subject matter-no doubt, both teachers experienced successes and failures but the fact that Mr. Smith was a native speaker and that Mr. Lau was not, certainly was not an issue here. And so, the question remains: Why does the native-speaker fallacy continue to play out in the educational sectors of Asia and throughout the world? We see countries throughout Asia offering substantial packages and incentives to draw native-English teachers; we see media stories depicting situations whereby 'native English' teachers have arrived from Canada and the U.S. only to be told they are ineligible because they are not white-many second generation Chinese and Japanese native English speakers are denied positions because they do not possess the 'white' face. Within ESL research, attention has been paid to race, ethnicity, culture and gender of learners, but far less attention has been given to how these variables in the teacher may impact the classroom (Amin, 1999, p. 35). Academic institutions throughout Asia have been the worst to popularize and legitimize the native speaker fallacy. It has been argued that this has contributed to the international hegemony of this discourse-ironically, "those whose interests may be harmed by this pedagogical assumption seem to implement it unquestionably” (Canagarajah, 1999, p. 83). 


\section{ECHOES OF CRUSOE}

The professional base of ELT is very narrow - today we continue to see remnants of the idealized native speaking teacher such as Dr. Higgins and Robinson Crusoe. Echoes of Crusoe and Higgins still reverberate as many members of the ELT profession have yet to learn the cultural lessons that "in order to understand ourselves, the discourse of the "other" --of all others-is that which we most urgently need to hear” (Brantlinger, 1992, p. 2). The term native speaker needs to be redefined to mean: proficient user of a languagenative-speakership should not be used as a criterion for excluding certain categories of people from language teaching-if it is ones accent and pronunciation that qualify one to be a teacher, then the sense of professionalism in ESL/EFL will continue to be flimsy and perhaps ultimately, extremely detrimental to language learners.

New beginnings represent newly found freedoms-It is these new times in which we can choose how to move beyond the limitations and cages that have been set up and perpetuated throughout the decades. I personally enjoy the notion of freedom found in Kingsolver's "The Poisonwood Bible." This story takes us on a journey into the Belgian Congo in 1959. It tells the story of Baptist minister who moves his family into the Congo. When they arrive at the remote village, they are greeted at the door of their new home by a caged bird. This bird is eventually banished from the house because he awakens the family each morning speaking impolite words which were taught to him by his former owner.

The bird's new freedom, however, proves overwhelming-he perches himself in an avocado tree beside the house and continues to reside in that very tree until the end of his days. He is described as sitting in the tree because he was 'unprepared for a new season of over whelming freedom (1998, p. 98). He 'had no wings' (p. 228). He depended on his family for his food and protection — he had no means to begin a new life. One morning, the minister's daughter finds the remains of the bird-she describes it as seeing a single red feather- "only feathers, without the ball of Hope inside. Feathers at last and no words at all” (p. 211-212).

The linguistic fallacy of the native speaker has prevailed throughout the centuries, throughout the world, throughout the literature we read----------now is the perfect opportunity as Cambodia begins the process of higher education and faculty development to take the freedom of designing hiring practices and ideological perceptions that will challenge and dismiss the notion of: only white faces/only native-speaking teachers need apply! 


\section{References}

Amin, N. (1999). Minority women teachers of ESL: Negotiating White English. In G. Braine (Ed.), Non-native Educators in English Language Teaching, Mahwah, NJ: Lawrence Erlbaum Publishers, Inc, pp. 93-104.

Auerbach, E. (1993). Re-examining English Only in the ESL classroom. Teachers of English to Speakers of Other Languages (TESOL) Quarterly, 27(1), 9-32.

Brantlinger, P. (1990). Crusoe's footprints: Cultural studies in Britain and America. New York, NY, USA: Routledge.

Canagarajah, A.S. (1999). Interrogating the "native-speaker fallacy": Non-linguistic Roots, nonpedagogical results. In G. Braine (Ed.), Non-native Educators in English Language Teaching. Mahway, NJ, USA: Lawrence Erlbaum Associates, Publishers, pp. 77-92.

Hamm, J. (1996). Caliban, Friday and their master. In L. Spass and B. Stimpson ( Eds.), Robinson Crusoe: Myths and metamorphoses (pp. 110-122). New York: St. Martin’s Press.

Kingsolver, B. (1998). The Poisonwood Bible. U.S.A: Harper Collins.

Paley, J. \& Jipson, I. (2000). Questions of you and the struggle of collaborative life. Counterpoints: Studies in Postmodern theory of education, Vol. 104. New York: Peter Lang Publishing Inc.

Parakrama, A. (1995). De-hegemonizing language standards. Learning from (Post) Colonial English about 'English'. London: Macmillan Press.

Pennycook, A. (1994). The cultural politics of English as an international language. New York, NY, USA: Longman.

Phillipson, R. (1992). Linguistic imperialism. Oxford, UK: Oxford University Press.

Savignon, S.J. (2003). Communicative language teaching: Linguistic theory and Classroom practice. In S.J. Savignon (Ed.), Interpreting communicative language teaching: Context and concerns in teacher education, New Haven, CT, USA: Yale University Press, pp.1-28.

Widdowson, H.G. (1994). The ownership of English. TESOL Quarterly, 28, 377-389.

Teresa L. Van Deven is an Associate Professor in the Department of Medical Imaging at the Schulich School of Medicine \& Dentistry at the University of Western Ontario. She previously worked in language education in Southeast Asia from 1996-2006. She continues to research and participate in second language education. She can be reached at tvandev@uwo.ca. 